\title{
BRAND AWARENESS MEMEDIASI PENGARUH SOCIAL MEDIA MARKETING TERHADAP KEPUTUSAN PEMBELIAN
}

\author{
Made Wahyu Krisna Upadana ${ }^{1}$ \\ Komang Agus Satria Pramudana ${ }^{2}$ \\ ${ }^{1,2}$ Fakultas Ekonomi dan Bisnis Universitas Udayana (Unud), Bali, Indonesian \\ email: madewahyu789@gmail.com
}

\begin{abstract}
ABSTRAK
Starbucks Coffee dalam menghadapi persaingan harus mampu berkembang dan berinovasi menentukan strategi yang efektif. Salah satunya dengan menggunakan social media marketing yang menarik guna menumbuhkan brand awareness di benak konsumen, sehingga menimbulkan keputusan pembelian pada konsumen. Tujuan penelitian untuk mengetahui peran brand awareness memediasi pengaruh social media marketing terhadap keputusan pembelian. Penelitian ini dilakukan di Kota Denpasar dengan 110 responden melalui metode purposive sampling. Pengumpulan data dilakukan melalui penyebaran kuesioner dan dianalisis dengan path analysis. Berdasarkan hasil analisis, social media marketing berpengaruh positif dan signifikan terhadap keputusan pembelian. Hal ini menunjukkan bahwa semakin baik penggunaan social media marketing yang dilakukan maka semakin meningkat pula keputusan pembelian dari konsumen. Brand awareness memediasi secara positif dan signifikan hubungan social media marketing terhadap keputusan pembelian. Brand awareness mampu memediasi hubungan social media marketing terhadap keputusan pembelian
\end{abstract}

Kata kunci: social media marketing, brand awareness, keputusan pembelian.

\section{ABSTRACT}

In order to stay in competition, Starbucks Coffee must be able to develop and innovate to determine an effective strategy. One of them is by using attractive social media marketing to builds brand awareness and leading to consumer purchasing decisions. The research objective is to determine the role of brand awareness mediating the effect of social media marketing on purchasing decisions. This research was conducted in Denpasar with 110 respondents through a purposive sampling method. Data collected through questionnaires and analyzed by path analysis. Based on the results, social media marketing has apositive and significant effect on purchasing decisions. This shows that the better the use of social media marketing, the more purchasing decisions from consumers. Brand awareness positively and significantly mediates the relationship between social media marketing and purchasing decisions. Brand awareness is able to mediate the relationship of social media marketing to purchasing decisions

Keywords: social media marketing, brand awareness, purchasing decisions. 


\section{PENDAHULUAN}

Manusia adalah makhluk sosial dimana setiap individunya memerlukan kegiatan berkomunikasi dengan orang lain. Di era globalisasi saat ini teknologi telah berkembang pesat. Adanya kebutuhan akan sosialisasi, banyak orang menciptakan inovasi baru dengan memanfaatkan kemajuan tekonologi untuk bersosialisasi. Salah satunya adalah internet, internet (Interconnected Network) adalah jaringan komputer yang menghubungkan antar jaringan secara global, internet dapat juga disebut jaringan dalam suatu jaringan yang luas. Adanya internet dapat menyimpan berbagai jenis informasi yang tidak terbatas. Internet sangat berperan sebagai sarana komunikasi, publikasi, serta sarana untuk mendapatkan berbagai informasi yang dibutuhkan. Kini hampir seluruh masyarakat di berbagai belahan dunia membutuhkan internet (Kshetri \& Jha, 2016).

Tabel 1.

Data Pengguna Internet di Indonesia

\begin{tabular}{lc}
\hline \multicolumn{1}{c}{ Data } & Total \\
\hline Populasi & 268.2 juta \\
Berlangganan seluler & 355,5 juta \\
Pengguna internet & 150,0 juta \\
Pengguna aktif di social media & 150,0 juta \\
Pengguna social media melalui seluler & 130,0 juta \\
\hline Sumber: Data Diolah, 2019
\end{tabular}

Pengguna internet di Indonesia sendiri mencapai 150 juta dari total penduduk Indonesia 268,2 juta jiwa. 150 juta jiwa aktif menggunakan social media dan 130 juta jiwa aktif menggunakan social media melalui seluler. Perkembangan tersebut membawa dampak perubahan pada pola gaya hidup di masyarakat yang menyebabkan seluruh industri atau perusahaan untuk bersaing menciptakan suatu inovasi yang baru dan kreatif untuk di produksi dan dipasarkan kepada masyarakat. Salah satu gaya hidup modern saat ini adalah kebiasaan individu atau kelompok tertentu yang hang out di kedai kopi atau coffee shop. Saat ini kedai kopi sudah menjamur hampir di seluruh sudut Ibu Kota Denpasar. Biasanya pengunjung akan berlama-lama berada di kedai kopi untuk menikmati secangkir kopi, hidangan kue, serta berbincang-bincang. Starbucks Coffee menjadi salah satu pilihan masyarakat saat ini. Kopi dari Starbucks Coffee telah menjadi fenomena dalam masyarakat di mana tampilan dari kopi ini memiliki desain yang menarik dengan teknologi canggih, tanpa meninggalkan ciri khas dari Starbucks itu sendiri.

Tabel 2.

Top Brand Index 2018 Fase 2 Kategori Retail

\begin{tabular}{lcccc}
\hline \multirow{2}{*}{ Merek } & \multicolumn{2}{c}{ 2017 } & \multicolumn{2}{c}{$\mathbf{2 0 1 8}$} \\
\cline { 2 - 5 } & TBI (persen) & TOP & TBI (persen) & TOP \\
\hline Starbucks & 39.5 & 1 & 51.9 & 1 \\
Excellso & 5.5 & 2 & - & - \\
The Coffee Bean \& Tea & 4.5 & 3 & 8.6 & 2 \\
Leaf & & & & \\
\hline
\end{tabular}

Sumber: Data Diolah, 2019 
Berdasarkan Tabel 2. dapat dilihat bahwa Starbucks Coffee unggul menjadi TOP Brand Index 2018 fase 2 kategori retail, mengalahkan The Coffee Bean \& Tea Leaf sebesar 51.9 persen. Starbucks Coffee mulai masuk ke Indonesia pada tanggal 17 Mei 2002 di Plaza Indonesia. Saat ini Starbucks telah memiliki 326 kedai di 22 kota di Indonesia. Di Kota Denpasar terdapat enam kedai sampai dengan tahun 2019. Munculnya pesaing dengan jenis usaha yang sama yaitu Excellso dan The Coffee Bean \& Tea Leaf, hal ini tidak menjadi hambatan untuk Starbucks Coffee bersaing dalam memasarkan produknya, terbukti sampai saat ini Starbucks masih menjadi TOP Brand di Indonesia.

Di era globalisasi sekarang ini, teknologi informasi berperan sangat penting, dengan menguasai teknologi dan informasi, perusahaan memiliki modal yang cukup besar untuk menjadi pemenang dalam persaingan global. Sebagai kedai kopi terbesar di dunia, Starbucks Coffee melakukan promosi dengan memanfaatkan social media. Social media adalah media online di mana para penggunanya dapat dengan mudah untuk berpartisipasi, berbagi dan berkomunikasi dengan semua orang diseluruh dunia tanpa ada batasan. Social media merupakan bagian penting dari strategi penjualan, pelayanan, komunikasi, dan pemasaran yang lebih besar dan lebih lengkap serta merefleksikan dan menyesuaikan diri dengan pasar dan orangorang yang mengartikannya. Ketatnya persaingan usaha yang kian berkembang, social media marketing yang dilakukan pun harus kreatif dan menarik untuk membentuk brand awareness. Merek suatu produk yang sudah dikenal dapat membuat konsumen merasa aman karena dapat terhindar dari resiko yang dapat merugikan konsumen. Perusahaan perlu melakukan pendekatan kepada konsumen dalam upaya membentuk brand awareness di benak konsumennya, agar mudah mengenali merek suatu produk di antara merek lainnya. Produk yang mudah diingat dan penggunaan simbol pada merek mampu menciptakan brand awareness

Brand awareness yang tinggi pada suatu produk dapat menjadi langkah awal saat konsumen memiliki keputusan atau niat beli terhadap produk tersebut. Menurut Herdana (2015) menyatakan konsumen cenderung membeli suatu produk dengan merek yang sudah dikenal ataupun yang sudah diingat, dibandingkan dengan produk yang masih terdengar asing di telinga mereka. Brand awareness yang telah dibentuk oleh Starbucks Coffee sebagai kedai kopi yang mempunyai peringkat tertinggi berhasil membuat konsumen menjadi loyal dalam menggunakan produk ini meskipun harus mengeluarkan uang yang tidak sedikit. Keberhasilan suatu perusahaan dalam menciptakan brand awareness tidak lepas dari adanya social media marketing, dengan tujuan untuk memperkenalkan dan menawarkan keunggulan produk pada konsumen.

Sebelum membeli suatu produk atau jasa tersebut, konsumen tentunya harus mempertimbangkan beberapa hal untuk mengambil keputusan, keputusan ini biasa disebut dengan keputusan konsumen. Keputusan pembelian konsumen adalah membeli merek yang disukai dari berbagai alternatif yang ada, tetapi dua faktor bisa berada antara niat pembelian dan keputusan pembelian. Keputusan pembelian konsumen adalah tahap di mana pembeli telah menentukan pilihannya dan melakukan pembelian produk, serta mengkonsumsinya. Selama proses pengambilan keputusan, konsumen memilih produk-produk dengan merek yang mereka sadari atau ingat. Ini merupakan beragam pertimbangan yang penting, 
karena merek yang memiliki top of mind yang tinggi memiliki kemungkinan paling tinggi untuk dipilih oleh konsumen.

Beberapa penelitian sebelumnya yang meneliti pengaruh social media marketing terhadap keputusan pembelian. Hasil penelitan yang dilakukan Mileva \& Fauzi (2018) menyatakan bahwa social media marketing berpengaruh signifikan terhadap keputusan pembelian. Artinya bahwa social media marketing yang dilakukan oleh Starbucks Coffee sudah baik, sehingga apabila perusahaan semakin melakukan pendekatan kepada konsumen yang dapat meningkatkan social media marketing lebih baik lagi, maka hal ini bisa meningkatkan keputusan pembelian konsumen terhadap produk Starbucks Coffee. Penelitian ini sejalan dengan penelitian yang dilakukan Putri (2016) serta Lubis \& Wibowo (2016) yang menunjukkan bahwa social media marketing berpengaruh positif dan signifikan terhadap keputusan pembelian.

Hasil penelitian yang dilakukan Muslim (2018) menunjukkan bahwa social media tidak berpengaruh signifikan terhadap keputusan pembelian, meskipun saat ini social media dianggap sebagai sarana yang cukup ampuh dalam mempengaruhi keputusan pembelian masyarakat karena social media saat ini masih sebatas pada penyebaran informasi produk. Penelitian yang dilakukan Edyl \& Brotojoyo (2017) juga mendapatkan hasil yang sama yaitu social media tidak berpengaruh signifikan terhadap keputusan pembelian, bahwa lifestyle kurang efektif dalam memediasi hubungan social media terhadap keputusan pembelian. Pra-survei yang dilakukan peneliti untuk mengetahui fenomena social media marketing, dan keputusan pembelian yang terjadi pada konsumen produk Starbucks Coffee di Kota Denpasar. Pra-survei penelitian ini dilakukan dengan cara menyebar kuesioner secara online pada 11 orang responden yang sudah pernah melakukan pembelian produk dari Starbucks Coffee di Kota Denpasar dapat dilihat pada Tabel 3.

Tabel 3.

Pra Survei Penelitian Starbucks Coffee di Kota Denpasar

\begin{tabular}{|c|c|c|c|}
\hline \multirow[t]{2}{*}{ No. } & \multirow[t]{2}{*}{ Pernyataan } & \multicolumn{2}{|c|}{ Jumlah Responden } \\
\hline & & Ya & Tidak \\
\hline 1. & $\begin{array}{l}\text { Starbucks Coffee memberikan fasilitas member card } \\
\text { yang terhubung dengan social media. }\end{array}$ & 7 & 4 \\
\hline 2. & $\begin{array}{l}\text { Starbucks Coffee mampu membangun komunikasi } \\
\text { dengan konsumennya melalui social media. }\end{array}$ & 6 & 5 \\
\hline 3. & $\begin{array}{l}\text { Starbucks Coffee menggunakan social media } \\
\text { sebagai wadah penyampaian kritik dan saran bagi } \\
\text { konsumen. }\end{array}$ & 5 & 6 \\
\hline 4. & $\begin{array}{l}\text { Saya memprioritaskan untuk membeli produk } \\
\text { Starbucks Coffee dibandingkan produk lain. }\end{array}$ & 4 & 7 \\
\hline 5. & $\begin{array}{l}\text { Saya bersedia berkorban waktu dan biaya untuk } \\
\text { membeli produk Starbucks Coffee. }\end{array}$ & 3 & 8 \\
\hline
\end{tabular}

Sumber: Data Diolah, 2019

Hasil pra-survei pada Tabel 3. yang dilakukan terhadap 11 responden yang sudah pernah melakukan pembelian produk pada Starbucks Coffee di Kota Denpasar menunjukkan adanya fenomena social media marketing, dan keputusan 
pembelian dilihat dari pernyataan nomor satu "Starbucks Coffee memberikan fasilitas member card yang terhubung dengan social media" tujuh responden menjawab ya menggunakan member card dan empat responden menjawab tidak. Pernyataan nomor tiga "Starbucks Coffee menggunakan social media sebagai wadah penyampaian kritik dan saran bagi konsumen" menunjukan bahwa lima responden menjawab ya dan enam responden menjawab tidak. Sedangkan pada pernyataan nomor lima "Saya bersedia berkorban waktu dan biaya untuk membeli produk Starbucks Coffee" tiga responden bersedia berkorban waktu dan biaya untuk membeli produk Starbucks, sedangkan delapan responden mengatakan tidak bersedia.

Tujuan penelitian ini adalah untuk menjelaskan pengaruh social media marketing terhadap brand awareness pada produk Starbucks Coffee di Kota Denpasar, untuk menjelaskan pengaruh social media marketing terhadap keputusan pembelian pada produk Starbucks Coffee di Kota Denpasar, untuk menjelaskan pengaruh brand awareness terhadap keputusan pembelian pada produk Starbucks Coffee di Kota Denpasar dan untuk menjelaskan peran brand awareness memediasi pengaruh social media marketing terhadap keputusan pembelian pada produk Starbucks Coffee di Kota Denpasar.

Penelitian sebelumnya yang dilakukan oleh Ayuningtyas et al. (2019) menjelaskan bahwa Terpaan Social media Instagram memiliki pengaruh langsung dan signifikan terhadap keputusan berkunjung. Chang (2016) di mana pengaruh dalam online communities yang merupakan bagian dari Community Building secara kuat akan positif meningkatkan pengaruh terhadap keputusan pembelian dengan adanya pengaruh dari opinion leaders yang berinteraksi dengan mereka. Hal ini sejalan dengan penelitian yang dilakukan oleh Jamaludin et al. (2015) menyimpulkan bahwa variabel promosi melaui social media berpengaruh signifikan terhadap variabel keputusan pembelian. Berdasarkan teori dan uraian tersebut, maka dapat disimpulkan hipotesis sebagai berikut:

$\mathrm{H}_{1}$ : Social media marketing berpengaruh positif dan signifikan terhadap keputusan pembelian.

Penelitian terdahulu dari Dewi \& Jatra (2018) mengatakan bahwa social media marketing menggunakan social media berpengaruh positif dan signifikan terhadap brand awareness. Tarigan \& Tritama (2016) juga menemukan bahwa Media Sosial berpengaruh positif pada Kesadaran Merek terhadap Produk Perusahaan. Elaydi (2018) juga menemukan bahwa Pemasaran Media Sosial berpengaruh pada Kesadaran Merek melalui Facebook pada Sektor Layanan Seluler di Mesir. Berdasarkan teori dan uraian tersebut, maka dapat disimpulkan hipotesis sebagai berikut:

$\mathrm{H}_{2}$ : Social media marketing berpengaruh positif dan signifikan terhadap brand awareness.

Siali \& Mahani (2016) yang menunjukkan bahwa kesadaran merek (brand awareness) memiliki hubungan yang signifikan dengan keputusan pembelian konsumen dalam merek internasional alas kaki. Penelitian yang dilakukan oleh Akhtar et al. (2015) menunjukkan bahwa hasil dari variabel brand awareness menunjukkan hasil yang dapat diandalkan. Dharma \& Sukaatmadja (2015) menyebutkan bahwa kesadaran merek (brand awareness) berpengaruh signifikan 
terhadap keputusan pembelian produk Apple di Kota Denpasar. Berdasarkan teori dan uraian tersebut, maka dapat disimpulkan hipotesis sebagai berikut:

$\mathrm{H}_{3}$ : Brand awareness berpengaruh positif dan signifikan terhadap keputusan pembelian.

Kesadaran konsumen yang tinggi akan kekuatan suatu merek dapat mampu mengenali atau mengingatnya. Saat ini masih banyak konsumen yang belum menyadari merek pada suatu produk karena kurangnya kegiatan pemasaran. Oleh karena itu, perusahaan harus melakukan upaya untuk menarik konsumen yang lebih banyak. Salah satunya adalah pemasaran internet. Internet adalah sisi pemasaran dari e-commerce, terdiri dari upaya perusahaan untuk berkomunikasi tentang mempromosikan dan menjual barang atau jasa melalui internet. Upaya tersebut dapat mempermudahkan dalam melakukan kegiatan pemasaran dengan memperluas jangkauan pasar. Perusahaan juga harus memberikan kebutuhan yang diinginkan konsumen sehingga dapat menjadi alternatif keputusan pembelian.

Sesuai dengan penelitian terdahulu menurut Goyal et al. (2019) dan Gabriel \& Kolapo (2015) menyatakan bahwa pemasaran internet mempunyai pengaruh terhadap keputusan pembelian secara positif dan signifikan. Sedangkan menurut Wibowo (2015) menyatakan bahwa pemasaran internet mempunyai pengaruh terhadap kesadaran merek secara positif dan signifikan. Berdasarkan teori dan uraian tersebut, maka dapat disimpulkan hipotesis sebagai berikut:

$\mathrm{H}_{4}$ : Brand awareness memediasi secara positif dan signifikan pengaruh social media marketing terhadap keputusan pembelian.

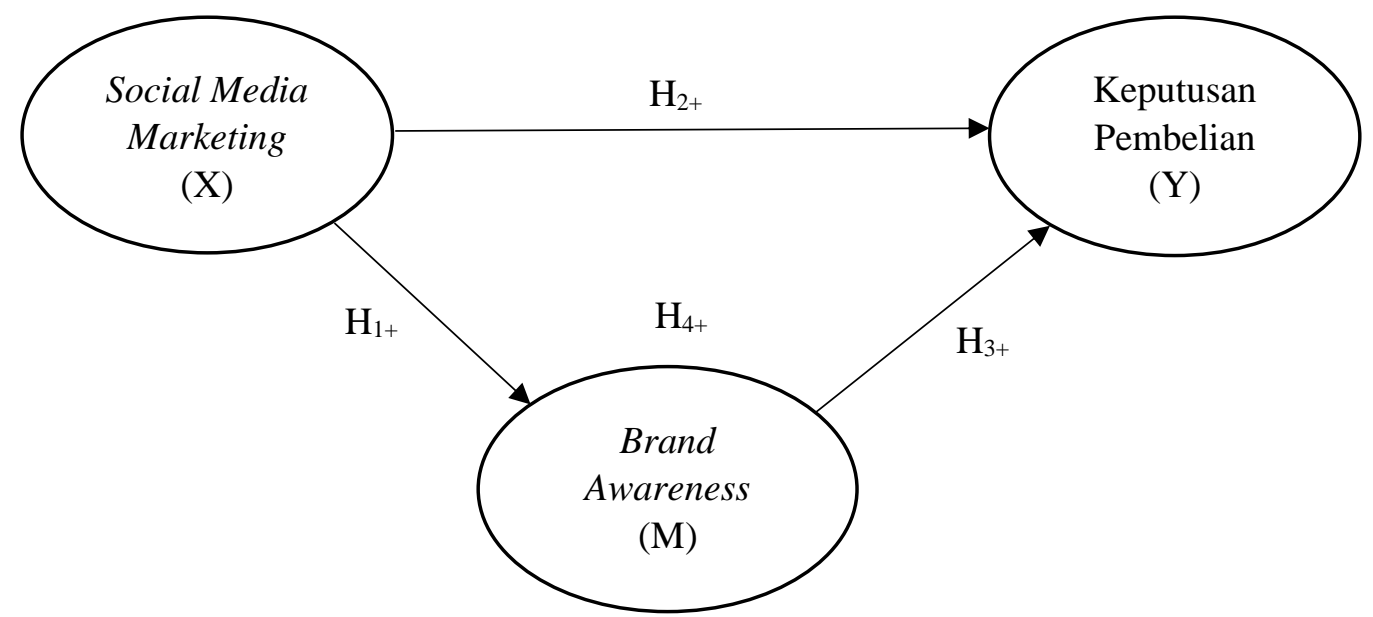

Gambar 1. Kerangka Konseptual

\section{METODE PENELITIAN}

Penelitian ini termasuk jenis penelitian dengan mengunakan pendekatan kuantitatif dengan metode asosiatif. Penelitian asosiatif bertujuan untuk menjelaskan pengaruh variabel social media marketing terhadap keputusan pembelian melalui brand awareness. Indikator-indikator setiap variabel mengacu pada beberapa sumber penelitian sebelumnya yang telah dimodifikasi menyesuaikan subjek penelitian ini. Penelitian ini dilakukan di Kota Denpasar. 
Kota Denpasar dipilih sebagai lokasi penelitian karena Kota Denpasar merupakan Ibu Kota Provinsi Bali dengan penduduk terpadat diantara kabupaten di Bali. Mobilitas masyarakat di Kota Denpasar yang cukup padat membuat pesaing kedai kopi banyak bermunculan yang menawarkan menu yang beragam dan tempat yang nyaman untuk hangout dan melepas penat. Salah satunya retail kedai kopi yang terkenal di Indonesia khususnya di Kota Denpasar adalah Starbucks Coffee yang hingga sekarang memiliki enam store di wilayah Kota Denpasar. Objek penelitian ini yaitu social media marketing, brand awareness, dan keputusan pembelian pada konsumen yang sudah pernah membeli produk Starbucks Coffee. Dalam penelitian ini, variabel tersebut adalah social media marketing $(\mathrm{X})$, variabel pemediasi adalah brand awareness (M) dan variabel terikat adalah keputusan pembelian (Y).

Social media marketing dalam penelitian ini merupakan bentuk pemasaran yang dipakai untuk meciptakan kesadaran, pengakuan, ingatan dan bahkan tindakan terhadap suatu merek, produk, bisnis, individu, atau kelompok baik secara langsung maupun tidak langsung dengan menggunakan alat dari web sosial seperti blogging, microblogging, dan jejaring sosial. Indikator social media marketing, yaitu: 1) Menjalin hubungan (relationship) artinya Starbucks Coffee menjalin hubungan melalui strategi member card yang terhubung ke social media seperti LINE 2) Komunikasi adalah interaksi yang terjadi antara barista Starbucks Coffee dengan konsumen. 3) Interaksi pasca pembelian, interaksi yang terjadi dengan konsumen setelah konsumen membeli produk Starbucks Coffee. 4) Format informasi artinya dapat menyampaikan informasi dengan lengkap produk dan promo produk beserta lokasinya di social media yang dimiliki oleh Starbucks Coffee.

Brand awareness dalam penelitian ini merupakan kemampuan seorang pelanggan untuk mengingat suatu merek atau iklan tertentu secara spontan maupun setelah dirangsang dengan kata-kata kunci. Indikator dari band awareness adalah: 1) Merek yang familiar, yaitu merek yang tidak asing terdengar ditelinga konsumen. 2) Merek yang terkenal, yaitu merek yang diketahui semua kalangan. 3) Merek yang dapat dibedakan dengan merek lain, yaitu konsumen mampu membedakan kopi merek Starbucks dengan merek lainnya melalui rasa, dan ciri khas kemasan dari Starbucks.

Keputusan pembelian dalam penelitian ini adalah suatu proses pengambilan keputusan yang diambil oleh seseorang dalam memilih salah satu alternatif yang ada melalui suatu proses evaluasi. Terdapat empat indikator keputusan pembelian yang disesuaikan berdasarkan penelitian ini adalah sebagai berikut: 1) Memutuskan untuk memilih. Dari berbagai gerai kedai kopi yang ada, memutuskan untuk memilih Starbucks Coffee sebagai tempat ngopi atau ngumpul bareng. 2) Prioritas, Memprioritaskan untuk membeli produk Starbucks Coffee dibandingkan produk lain. 3) Kesediaan berkorban, Kesediaan untuk berkorban (waktu, biaya, dan tenaga) mendapatkan produk dari Starbucks Coffee. 4) Menyukai produk, Konsumen merasa senang setelah membeli produk Starbucks Coffee.

Data kuantitatif adalah representasi realitas yang disimbolkan secara numerik atau angka. Data kuantitatif dalam penelitian ini adalah data pengguna internet di Indonesia, dan jumlah responden. Data kualitatif pada penelitian ini adalah pendapat responden terhadap pernyataan yang meliputi social media marketing, 
brand awareness, dan keputusan pembelian. Data primer yang dikumpulkan dalam penelitian ini adalah data yang terdiri dari kuesioner yang disebarkan kepada konsumen Starbucks Coffee di Kota Denpasar. Data sekunder adalah data yang mengacu pada informasi yang dikumpulkan dari sumber yang sudah ada. Data sekunder dalam penelitian ini diperoleh dari referensi pada buku, jurnal, internet dan lain sebagainya. Dalam penelitian ini, populasi yang digunakan adalah seluruh konsumen Kota Denpasar yang sudah pernah membeli produk dari Starbucks Coffee yang tidak diketahui jumlah pastinya (Infinite).

Penelitian ini dianalisis dengan multivariate dalam melakukan analisis maka jumlah anggota sampel disarankan minimal 5-10 kali dari jumlah indikator yang diteliti Jumlah indikator yang digunakan adalah 11 sehingga jumlah sampel yang diperlukan adalah 11 x $10=110$ responden. Dalam penelitian ini, teknik yang digunakan adalah purposive sampling yaitu teknik penentuan sampel dengan pertimbangan tertentu menggunakan kuesioner. Kuesioner tersebut diukur dengan menggunakan skala Likert dengan perhitungan nilai skala 1 sampai dengan 5. Untuk menganalisis data, penelitian ini menggunakan analisis regresi berganda. Kriteria penentuan sampel dalam penelitian ini adalah sebagai berikut: 1) Jenjang pendidikan minimal SMA/SMK sederajat dengan rentang usia mulai dari 17 tahun dengan alasan orang tersebut dapat mengerti maksud pertanyaan yang akan diajukan dan mampu menjawab pertanyaan dengan objektif. 2) Responden berdomisili di Kota Denpasar. 3) Responden yang sudah pernah membeli produk Starbucks Coffee di Kota Denpasar.

Pengumpulan data dalam penelitian ini dilakukan dengan menggunakan kuesioner. Kuesioner adalah teknik pengumpulan data dengan menyebarkan daftar pertanyaan secara tertulis mengenai objek penelitian, di mana kuesioner tersebut disebarkan secara langsung dan juga melalui google form. Kuesioner langsung diberikan kepada responden yang sedang berbelanja di seluruh outlet Starbucks Coffee Kota Denpasar. Kuesioner yang disebar dengan menggunakan google form diberikan kepada teman peneliti, di mana sebelumnya telah diketahui secara pasti bahwa responden pernah membeli dan menggunakan produk Starbucks Coffee.

\section{HASIL DAN PEMBAHASAN}

Starbucks mulai hadir di Indonesia pada tahun 2002 dan membuka gerai pertamanya di Semarang tepatnya di Paragon Mall pada tahun 2010, sedangkan Starbucks Ciputra mulai hadir pada tahun 2014. Starbucks mencoba mulai masuk ke dunia social media pada tahun 2014, dimana Starbucks membuat LINE Official Account untuk mempermudah menjangkau konsumen, dengan pengikutnya yang terbilang lebih banyak dari beberapa retail ternama yang ada. Awalnya social media yang digunakan hanyalah untuk menginformasikan varian produk terbaru minuman, tumbler, dan merchandise lainnya, seiring berkembangnya waktu Starbucks Coffee mulai menggunakan LINE Official Accountnya untuk promosi, dimana setiap minggunya Starbucks selalu memberikan promo menarik seperti by one get one, by two get three, dan setiap keluar varian produk terbaru pasti Starbucks memberikan harga yang spesial. 
Saat ini, Starbucks Coffee tidak hanya menjual kopi namun juga teh, minuman blended, minuman soda, dan berbagai macam makanan, hingga merchandise unik seperti membercard, tumbler, tas dan gantungan kunci. Fungsi dari membercard Starbucks yaitu untuk mendapatkan potongan harga membeli minuman ataupun makanan, mendapatkan reward gratis minuman atau makanan apa saja jika sudah mengumpulkan 100 point, dan apabila ada seseorang yang berulang tahun maka Starbucks Coffee akan memberikan minuman gratis kepada orang tersebut, sedangkan kegunaan tumbler itu sendiri untuk mengurangi penggunaan sampah plastik sekali pakai, dan uniknya setiap tanggal 20 Starbucks memperingati GRENEER DAY atau hari bebas sampah plastik dengan cara membawa tumbler Starbucks akan mendapatkan potongan setengah harga untuk minuman apapun, cara ini dirasa Starbucks sudah membantu untuk mengurangi penggunaan sampah plastik sekali pakai. Starbucks kini terus berinovasi dan menjadikan perusahaannya semakin ramah lingkungan. Dengan begitu, konsumennya menjadi semakin loyal karena secara tidak langsung merekapun turut membantu menjaga lingkungan ini tetap lestari dan terhindar dari sampah plastik.

Tabel 4.

Karakteristik Responden Menurut Jenis Kelamin

\begin{tabular}{cccc}
\hline No & Jenis Kelamin & Jumlah (Orang) & Jumlah (Persentase persen) \\
\hline 1 & Laki - Laki & 74 & 67,3 \\
2 & Perempuan & 36 & 32,7 \\
& Jumlah & 110 & 100 \\
\hline
\end{tabular}

Sumber: Data Diolah, 2019

Pada Tabel 4. dapat dilihat responden dengan jenis kelamin laki-laki lebih mendominasi yakni 74 orang atau 67,3 persen. Sedangkan responden dengan jenis kelamin perempuan sebanyak 36 orang atau 32,7 persen.

Tabel 5.

Karakteristik Responden Menurut Usia

\begin{tabular}{cccc}
\hline No & Umur (Tahun) & Jumlah (Orang) & $\begin{array}{c}\text { Jumlah (Persentase } \\
\text { persen) }\end{array}$ \\
\hline 1 & $17-21$ Tahun & 31 & 28,2 \\
2 & $22-26$ Tahun & 59 & 53,6 \\
3 & $27-32$ Tahun & 11 & 10,0 \\
4 & 33 - 38 Tahun & 9 & 8,2 \\
& Jumlah & 110 & 100 \\
\hline
\end{tabular}

Sumber: Data Diolah, 2019

Pada Tabel 5. dapat dilihat responden dengan usia dari 22 - 26 tahun yang paling mendominasi diantara usia lainnya yakni 59 orang atau 53,6 persen. Sedangkan responden dengan usia 33 - 38 tahun yang paling sedikit yakni 9 orang atau 8,2 persen.

Pada Tabel 6, dapat dilihat responden dengan tingkat pendidikan S1 yang paling mendominasi diantara tingkat pendidikan lainnya yakni 55 orang atau 50,0 
persen. Sedangkan responden yang paling sedikit adalah responden dengan tingkat pendidikan S2 yakni 4 orang atau 3,6 persen.

Tabel 6.

Karakteristik Responden Menurut Tingkat Pendidikan

\begin{tabular}{cccc}
\hline No & Pendidikan Terakhir & Jumlah (Orang) & $\begin{array}{c}\text { Jumlah (Persentase } \\
\text { persen) }\end{array}$ \\
\hline 1 & SMA & 28 & 25,5 \\
2 & Diploma & 23 & 20,9 \\
3 & S1 & 55 & 50,0 \\
4 & S2 & 4 & 3,6 \\
& Jumlah & 110 & 100 \\
\hline
\end{tabular}

Sumber: Data Diolah, 2019

Tabel 7.

Karakteristik Responden Menurut Pekerjaan

\begin{tabular}{cccc}
\hline No & Pekerjaan & Jumlah (Orang) & $\begin{array}{c}\text { Jumlah (Persentase } \\
\text { persen) }\end{array}$ \\
\hline 1 & Pelajar/Mahasiswa & 28 & 25,5 \\
2 & Pegawai Swasta & 9 & 8,2 \\
3 & Pegawai Negeri Sipil & 11 & 10,0 \\
4 & Wiraswasta & 52 & 47,3 \\
5 & Lainnya & 10 & 9,1 \\
& Jumlah & 110 & 100 \\
\hline
\end{tabular}

Sumber: Data Diolah, 2019

Pada Tabel 7. dapat dilihat responden dengan pekerjaan wiraswasta yang paling mendominasi diantara pekerjaan lainnya yakni 52 orang atau 47,3 persen. Sedangkan responden yang paling sedikit adalah responden dengan pekerjaan pegawai swasta yakni 9 orang atau 8,2 persen.

Tabel 8.

Rekapitulasi Hasil Uji Reliabilitas Instrumen Penelitian

\begin{tabular}{clc}
\hline No. & Variabel & Cronbach's Alpha \\
\hline 1 & Social Mediia Marketing $(\mathrm{X})$ & 0,891 \\
2 & Brand Awareness $(\mathrm{M})$ & 0,868 \\
3 & Keputusan Pembelian (Y) & 0,773 \\
\hline
\end{tabular}
Sumber: Data Diolah, 2019

Hasil uji reliabilitas yang disajikan dalam Tabel 8. menunjukkan bahwa seluruh instrumen penelitian memiliki koefisien Cronbach's Alpha lebih dari 0,60. Jadi dapat dinyatakan bahwa seluruh variabel telah memenuhi syarat reliabilitas atau kehandalan sehingga dapat digunakan untuk melakukan penelitian.

Hasil uji validitas pada Tabel 9. menunjukkan bahwa seluruh instrumen penelitian yang digunakan untuk mengukur variabel Social Media Marketing, Brand Awareness, dan Keputusan Pembelian memiliki nilai koefisien korelasi dengan skor total seluruh item pernyataan lebih besar dari 0,3. Hal ini 
menunjukkan bahwa butir-butir pernyataan dalam instrument penelitian tersebut valid dan layak digunakan sebagai instrument penelitian.

Tabel 9.

Rekapitulasi Hasil Uji Validitas Instrumen Penelitian

\begin{tabular}{|c|c|c|c|}
\hline Variabel & Indikator & $\begin{array}{c}\text { Koefisien } \\
\text { Korelasi }\end{array}$ & Koefisien Batas \\
\hline \multirow{4}{*}{ Social Media Marketing (X) } & $\mathrm{X}_{.1}$ & 0,894 & 0,3 \\
\hline & $\mathrm{X}_{.2}$ & 0,820 & 0,3 \\
\hline & $\mathrm{X}_{.3}$ & 0,862 & 0,3 \\
\hline & $\mathrm{X}_{4}$ & 0,914 & 0,3 \\
\hline \multirow{3}{*}{ Brand Awareness (M) } & $\mathrm{M}_{1}$ & 0,887 & 0,3 \\
\hline & $\mathrm{M}_{2}$ & 0,943 & 0,3 \\
\hline & M.3 & 0,854 & 0,3 \\
\hline \multirow{4}{*}{ Keputusan Pembelian (Y) } & $\mathrm{Y}_{\cdot 1}$ & 0,788 & 0,3 \\
\hline & $Y_{.2}$ & 0,849 & 0,3 \\
\hline & $\mathrm{Y}_{3} 3$ & 0,774 & 0,3 \\
\hline & Y.4 & 0,689 & 0,3 \\
\hline
\end{tabular}

Sumber: Data Diolah, 2019

Tabel 10.

Deskripsi Jawaban Responden Terhadap Social Media Marketing

\begin{tabular}{|c|c|c|c|c|c|c|c|c|}
\hline \multirow{2}{*}{ No } & \multirow{2}{*}{ Pernyataan } & \multicolumn{5}{|c|}{ Frekuensi Jawaban Responden } & \multirow{2}{*}{ Rata-Rata } & \multirow{2}{*}{ Kriteria } \\
\hline & & STS & TS & $\mathbf{N}$ & $\mathbf{S}$ & SS & & \\
\hline 1 & $\begin{array}{l}\text { Starbucks Coffee memberikan } \\
\text { informasi promosi pengguna } \\
\text { member card Starbucks } \\
\text { melalui social media. }\end{array}$ & 0 & 0 & 36 & 62 & 12 & 3,78 & Baik \\
\hline 2 & $\begin{array}{l}\text { Starbucks Coffee mampu } \\
\text { membangun komunikasi } \\
\text { dengan konsumennya melalui } \\
\text { social media. }\end{array}$ & 0 & 0 & 17 & 78 & 15 & 3,98 & Baik \\
\hline 3 & $\begin{array}{llr}\text { Starbucks } & \text { Coffee } \\
\text { menggunakan } & \text { social media } \\
\text { sebagai wadah penyampaian } \\
\text { kritik dan saran bagi } \\
\text { konsumen. }\end{array}$ & 0 & 1 & 11 & 73 & 25 & 4,11 & Baik \\
\hline 4 & $\begin{array}{l}\text { Starbucks Coffee mampu } \\
\text { menyampaikan informasi yang } \\
\text { lengkap mengenai produk, dan } \\
\text { lokasi store melaui social } \\
\text { media. } \\
\text { Rata-rata keseluruhan variab }\end{array}$ & Soci & 5 & 37 & 59 & 9 & 3,65 & Baik \\
\hline
\end{tabular}

Sumber: Data Diolah, 2019

Tabel 10. menunjukkan persepsi responden mengenai variabel social media marketing dengan rata-rata tertinggi pada pernyataan "Starbucks Coffee menggunakan social media sebagai wadah penyampaian kritik dan saran bagi konsumen", diperoleh nilai rata-rata sebesar 4,11 yang masuk kriteria baik, ini berarti secara umum Starbucks Coffee telah mampu menggunakan social media marketing sebagai sarana penyampaian kritik dan saran. 
Tabel 11.

Deskripsi Jawaban Responden Terhadap Variabel Brand Awareness

\begin{tabular}{|c|c|c|c|c|c|c|c|c|}
\hline \multirow{2}{*}{ No } & \multirow{2}{*}{ Pernyataan } & \multicolumn{5}{|c|}{ Frekuensi Jawaban Responden } & \multirow{2}{*}{ Rata-Rata } & \multirow{2}{*}{ Kriteria } \\
\hline & & STS & TS & $\mathbf{N}$ & $\mathbf{S}$ & $\mathbf{S S}$ & & \\
\hline 1 & $\begin{array}{l}\text { Starbucks Coffee adalah } \\
\text { merek yang tidak asing di } \\
\text { telinga saya }\end{array}$ & 1 & 11 & 45 & 46 & 7 & 3,43 & Baik \\
\hline 2 & $\begin{array}{l}\text { Starbucks Coffe adalah } \\
\text { merek yang terkenal }\end{array}$ & 3 & 11 & 45 & 41 & 10 & 3,40 & Baik \\
\hline 3 & $\begin{array}{l}\text { Saya dapat membedakan } \\
\text { produk merek Starbucks } \\
\text { Coffee dengan merek lain }\end{array}$ & 5 & 17 & 57 & 21 & 10 & 3,13 & $\begin{array}{l}\text { Cukup } \\
\text { Baik }\end{array}$ \\
\hline & Rata-rata keseluruhan va & riabe & and & are & & & 3,32 & $\begin{array}{l}\text { Cukup } \\
\text { Baik }\end{array}$ \\
\hline
\end{tabular}

Sumber: Data Diolah, 2019

Persepsiresponden mengenai variabel brand awareness dengan rata-rata tertinggi pada pernyataan "Starbucks Coffee adalah merek yang tidak asing di telinga saya", diperoleh nilai rata-rata sebesar 3,43 yang masuk kriteria baik, ini berarti Starbucks Coffee merupakan brand yang familiar di masyarakat.

Tabel 12.

Deskripsi Jawaban Responden Terhadap Variabel Keputusan Pembelian

\begin{tabular}{|c|c|c|c|c|c|c|c|c|}
\hline \multirow{2}{*}{ No } & \multirow{2}{*}{ Pernyataan } & \multicolumn{5}{|c|}{ FrekuensiJawaban Responden } & \multirow{2}{*}{ Rata-Rata } & \multirow{2}{*}{ Kriteria } \\
\hline & & STS & TS & $\mathbf{N}$ & $\mathbf{S}$ & SS & & \\
\hline 1 & $\begin{array}{l}\text { Dari berbagai kedai kopi yang } \\
\text { ada, saya memutuskan } \\
\text { Starbucks Coffee sebagai } \\
\text { tempat hangout dan minum } \\
\text { kopi. }\end{array}$ & 1 & 2 & 55 & 41 & 11 & 3,54 & Baik \\
\hline 2 & $\begin{array}{l}\text { Saya memprioritaskan untuk } \\
\text { membeli produk Starbucks } \\
\text { Coffee dibandingkan produk } \\
\text { lain. }\end{array}$ & 0 & 4 & 57 & 37 & 12 & 3,52 & Baik \\
\hline 3 & $\begin{array}{l}\text { Saya bersedia berkorban } \\
\text { waktu dan biaya untuk } \\
\text { membeli produk Starbucks } \\
\text { Coffee. }\end{array}$ & 1 & 11 & 59 & 34 & 5 & 3,28 & $\begin{array}{l}\text { Cukup } \\
\text { Baik }\end{array}$ \\
\hline 4 & $\begin{array}{l}\text { Saya merasa senang setelah } \\
\text { memutuskan membeli produk } \\
\text { Starbucks Coffee. } \\
\text { Rata-rata keseluruhan varia }\end{array}$ & gel Ker & tusa & 52 & 30 & 19 & 3,54 & Baik \\
\hline
\end{tabular}

Sumber: Data Diolah, 2019

Tabel 12. menunjukkan persepsi responden mengenai variabel keputusan pembelian dengan rata-rata tertinggi pada pernyataan "Dari berbagai kedai kopi yang ada, saya memutuskan Starbucks Coffee sebagai tempat hangout dan minum kopi", dan "Saya merasa senang setelah memutuskan membeli produk Starbucks 
Coffee" diperoleh rata-rata yang sama dengan nilai sebesar 3,54 yang masuk kriteria baik, ini berarti secara umum Starbucks tempat ngopi yang memberikan kesan yang baik sehingga konsumen menjadi senang.

Tabel 13.

Hasil Uji Normalitas Struktur 1

\begin{tabular}{lc}
\hline & Unstandardized Residual \\
\hline $\mathrm{N}$ & 110 \\
Test Statistics & 0,067 \\
Asymp. Sig. (2-tailed) & 0,200 \\
\hline
\end{tabular}

Sumber: Data Diolah, 2019

Berdasarkan Tabel 13. dapat dilihat bahwa nilai Asymp. Sig. (2-tailed) sebesar 0,200, hasil tersebut mengindikasikan bahwa model persamaan regresi tersebut berdistribusi normal karena nilai Asymp. Sig. (2-tailed) lebih besar dari nilai alpha 0,05 .

Tabel 14.

Hasil Uji Normalitas Struktur 2

\begin{tabular}{lc}
\hline & Unstandardized Residual \\
\hline $\mathrm{N}$ & 110 \\
Test Statistics & 0,058 \\
Asymp. Sig. (2-tailed) & 0,200 \\
\hline
\end{tabular}

Sumber: Data Diolah, 2019

Berdasarkan Tabel 14. dapat dilihat bahwa nilai Asymp. Sig. (2-tailed) sebesar 0,200, hasil tersebut mengindikasikan bahwa model persamaan regresi tersebut berdistribusi normal karena nilai Asymp. Sig. (2-tailed) lebih besar dari nilai alpha 0,05 .

Tabel 15.

Hasil Uji Multikoleniaritas

\begin{tabular}{llcc}
\hline \multicolumn{1}{c}{ Persamaan Struktur } & \multicolumn{1}{c}{ Variabel } & Tolerance & VIF \\
\hline $\mathrm{M}=\beta_{1} \mathrm{X}+\mathrm{e}_{1}$ & Social Media Marketing $(\mathrm{X})$ & 1,000 & 1,000 \\
$\mathrm{Y}=\beta_{1} \mathrm{X}+\beta_{2} \mathrm{M}+\mathrm{e}_{2}$ & Social Media Marketing $(\mathrm{X})$ & 0,450 & 2,224 \\
& Brand Awareness $(\mathrm{M})$ & 0,450 & 2,224 \\
\hline
\end{tabular}

Sumber: Data Diolah, 2019

Berdasarkan Tabel 15. dapat dilihat bahwa nilai tolerance dan VIF dari variabel Social Media Marketing dan Brand Awareness menunjukkan nilai tolerance untuk setiap variabel lebih besar dari 0,1 dan nilai VIF lebih kecil dari 10 yang berarti model persamaan regresi bebas dari multikolinearitas.

Pada Tabel 16. dapat dilihat bahwa nilai signifikansi dari variabel Social Media Marketing sebesar 0,623. Nilai tersebut lebih besar dari 0,05 yang berarti tidak terdapat pengaruh antara variabel bebas terhadap absolute residual. Dengan demikian, model yang dibuat tidak mengandung gejala heteroskedastisitas. 
Tabel 16.

Hasil Uji Heteroskedastisitas Struktur 1

\begin{tabular}{|c|c|c|c|c|c|}
\hline \multirow[t]{2}{*}{ Model } & \multicolumn{2}{|c|}{$\begin{array}{c}\text { Unstandardized } \\
\text { Coefficients }\end{array}$} & \multirow{2}{*}{$\begin{array}{c}\begin{array}{c}\text { Standardized } \\
\text { Coefficients }\end{array} \\
\text { Beta }\end{array}$} & \multirow[t]{2}{*}{$\mathbf{t}$} & \multirow[t]{2}{*}{ Sig. } \\
\hline & B & Std. Error & & & \\
\hline (Constant) & 0.966 & .658 & & 1.469 & .145 \\
\hline $\begin{array}{l}\quad \text { Social Media } \\
\text { Marketing } \\
\text { a. Dependent Vari }\end{array}$ & $\begin{array}{r}.021 \\
\mathrm{RES} 1\end{array}$ & .042 & .047 & .492 & .623 \\
\hline
\end{tabular}

Tabel 17.

Hasil Uji Heteroskedastisitas Struktur 2

\begin{tabular}{|c|c|c|c|c|c|}
\hline \multirow[t]{2}{*}{ Model } & \multicolumn{2}{|c|}{$\begin{array}{l}\text { Unstandardized } \\
\text { Coefficients }\end{array}$} & \multirow{2}{*}{$\begin{array}{c}\begin{array}{c}\text { Standardized } \\
\text { Coefficients }\end{array} \\
\text { Beta }\end{array}$} & \multirow[t]{2}{*}{$\mathbf{t}$} & \multirow[t]{2}{*}{ Sig. } \\
\hline & B & $\begin{array}{c}\text { Std. } \\
\text { Error }\end{array}$ & & & \\
\hline (Constant) & .054 & .477 & & .114 & .909 \\
\hline $\begin{array}{l}\text { Social Media } \\
\text { Marketing }\end{array}$ & .057 & .044 & .185 & 1.304 & 195 \\
\hline Brand Awareness & -.007 & .039 & -.026 & -.186 & .853 \\
\hline
\end{tabular}
a. Dependent Variabel: ABS_RES2

Sumber: Data Diolah, 2019

Pada Tabel 17. dapat dilihat bahwa nilai signifikansi dari variabel Social Media Marketing dan Brand Awareness, masing-masing sebesar 0,195 dan 0,853. Nilai tersebut lebih besar dari 0,05 yang berarti tidak terdapat pengaruh antara variabel bebas terhadap absolute residual. Dengan demikian, model yang dibuat tidak mengandung gejala heteroskedastisitas.

Tabel 18.

Hasil Analisis Jalur 1

\begin{tabular}{|c|c|c|c|c|c|c|}
\hline \multirow{2}{*}{\multicolumn{2}{|c|}{ Model }} & \multicolumn{2}{|c|}{$\begin{array}{l}\text { Unstandardized } \\
\text { Coefficients }\end{array}$} & \multirow{2}{*}{$\begin{array}{c}\begin{array}{c}\text { Standardized } \\
\text { Coefficients }\end{array} \\
\text { Beta } \\
\end{array}$} & \multirow[t]{2}{*}{$\mathbf{t}$} & \multirow[t]{2}{*}{ Sig. } \\
\hline & & B & Std. Error & & & \\
\hline \multirow[t]{2}{*}{1} & (Constant) & -3.087 & 1.144 & & -2.698 & .008 \\
\hline & $\begin{array}{l}\text { Social Media } \\
\text { Marketing }\end{array}$ & .840 & .073 & .742 & 11.499 & .000 \\
\hline \multirow{3}{*}{\multicolumn{2}{|c|}{$\begin{array}{l}\text { R Square } \\
\text { F Statistik } \\
\text { Sig. Uji F }\end{array}$}} & 0,550 & & & & \\
\hline & & 132.229 & & & & \\
\hline & & 0,000 & & & & \\
\hline
\end{tabular}

Nilai koefisien regresi variabel Social Media Marketing bernilai positif dengan nilai signifikansi uji t kurang dari 0,05. Hal ini menunjukkan bahwa variabel Social Media Marketing memiliki pengaruh positif yang signifikan terhadap variabel Brand Awareness. Besarnya pengaruh variabel bebas terhadap variabel terikat yang ditunjukkan oleh nilai determinasi total (R Square) sebesar 0,550 mempunyai arti bahwa sebesar 55 persen variasi Brand Awareness dipengaruhi 
oleh variasi Social Media Marketing sedangkan sisanya sebesar 45 persen dijelaskan oleh faktor lain yang tidak dimasukkan ke dalam model.

Tabel 19.

Hasil Analisis Jalur 2

\begin{tabular}{lcccccc}
\hline \multirow{2}{*}{ Variabel } & \multicolumn{2}{c}{$\begin{array}{c}\text { Unstandardized } \\
\text { Coefficients }\end{array}$} & $\begin{array}{c}\text { Standardized } \\
\text { Coefficients } \\
\text { Beta }\end{array}$ & t hitung & $\begin{array}{c}\text { Sig. } \\
\text { uji t }\end{array}$ \\
\cline { 2 - 3 } & B & Std. Error & & & 3.851 & .000 \\
\hline (Constant) & 3.141 & .816 & & .466 & 6.005 & .000 \\
Social Media & .451 & .075 & .437 & 5.631 & .000 \\
Marketing (X) & .374 & .066 & & & \\
Brand Awareness(M) & 0,843 & & & & \\
\hline R Square & 131.162 & & & & &
\end{tabular}

Nilai koefisien regresi masing-masing variabel bebas bernilai positif dengan nilai signifikansi uji t kurang dari 0,05. Hal ini menunjukkan bahwa semua variabel bebas memiliki pengaruh positif yang signifikan terhadap variabel terikat. Besarnya pengaruh variabel bebas terhadap variabel terikat yang ditunjukkan oleh nilai determinasi total ( $\mathrm{R}$ Square) sebesar 0,843 mempunyai arti bahwa sebesar 71,0 persen variasi Keputusan Pembelian dipengaruhi oleh variasi Social Media Marketing dan Brand Awareness, sedangkan sisanya sebesar 15,7 persen dijelaskan oleh faktor lain yang tidak dimasukkan ke dalam model. Nilai determinasi total sebesar 0,869 mempunyai arti bahwa sebesar 86,9 persen variasi Keputusan Pembelian dipengaruhi oleh variasi Social Media Marketing dan Brand Awareness, sedangkan sisanya sebesar 13,1 persen dijelaskan oleh faktor lain yang tidak dimasukkan ke dalam model.

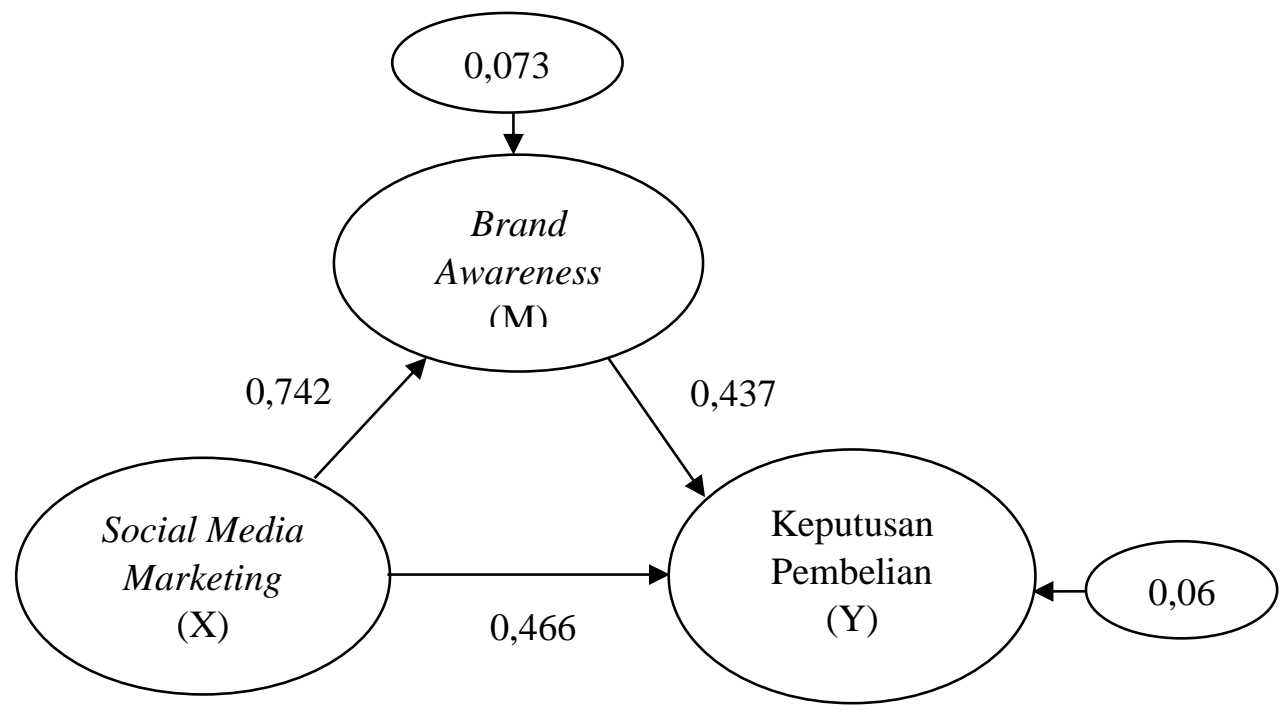

Gambar 2. Validasi Diagram Jalur Akhir 
Berdasarkan diagram jalur pada Gambar 2. maka dapat dihitung besarnya pengaruh langsung dan pengaruh tidak langsung serta pengaruh total antar variabel. Perhitungan pengaruh antar variabel dirangkum dalam Tabel 20, sebagai berikut.

Tabel 20.

\begin{tabular}{|c|c|c|c|}
\hline \multicolumn{4}{|c|}{$\begin{array}{c}\text { Pengaruh Langsung dan Pengaruh Tidak Langsung serta Pengaruh Total } \\
\text { Social Media Marketing (X), Brand Awareness (M), dan Keputusan } \\
\text { Pembelian (Y) }\end{array}$} \\
\hline $\begin{array}{c}\text { Pengaruh } \\
\text { Variabel }\end{array}$ & $\begin{array}{l}\text { Pengaruh } \\
\text { Langsung }\end{array}$ & $\begin{array}{c}\text { Pengaruh Tidak Langsung Melalui } \\
\text { Brand Awareness } \\
\text { (Y1) }(\beta 1 \times \beta 3)\end{array}$ & Pengaruh Total \\
\hline $\mathrm{X} \rightarrow \mathrm{M}$ & 0,742 & - & 0,742 \\
\hline $\mathrm{X} \rightarrow \mathrm{Y}$ & 0,466 & 0,324 & 0,790 \\
\hline $\mathrm{M} \rightarrow \mathrm{Y}$ & 0,437 & - & 0,437 \\
\hline
\end{tabular}

Sumber: Data Diolah, 2019

Tabel 20. menunjukkan bahwa pengaruh langsung Social Media Marketing terhadap Brand Awareness adalah sebesar 0,742. Pengaruh langsung variabel Social Media Marketing terhadap Keputusan Pembelian sebesar 0,466. Pengaruh langsung variabel Brand Awareness terhadap Keputusan Pembelian sebesar 0,437. Hal ini berarti bahwa variabel Keputusan Pembelian lebih besar dipengaruhi oleh Social Media Marketing dari Brand Awareness. Sedangkan pengaruh tidak langsung variabel Social Media Marketing terhadap Keputusan Pembelian melalui Brand Awareness sebesar 0,324. Jadi pengaruh total variabel Social Media Marketing terhadap Keputusan Pembelian melalui Brand Awareness adalah sebesar 0,790. Jadi dapat disimpulkan bahwa lebih besar total pengaruh Social Media Marketing terhadap Keputusan Pembelian yang melalui Brand Awareness, daripada pengaruh langsung Social Media Marketing terhadap Keputusan Pembelian tanpa melalui variabel Brand Awareness.

Berdasarakn uji sobel, didapat $\mathrm{Z}$ hitung sebesar 4,157 > 1,96. Artinya Brand Awareness menjadi mediasi pada hubungan Social Media Marketing terhadap Keputusan Pembelian. Keputusan Pembelian diperoleh nilai Signifikansi sebesar 0,000 dengan nilai koefisien beta 0,466 bernilai positif. Nilai Signifikansi $0,000<$ 0,05 mengindikasikan bahwa $\mathrm{H}_{0}$ ditolak dan $\mathrm{H}_{2}$ diterima. Hasil ini mempunyai arti bahwa Social Media Marketing berpengaruh positif dan signifikan terhadap Keputusan Pembelian. Hal ini menandakan semakin baik Social Media Marketingnya, maka Keputusan Pembelian pada produk Starbucks Coffee akan semakin baik. Hal ini sejalan dengan penelitian sebelumnya yang dilakukan oleh oleh Ayuningtyas et al. (2019), Chang (2016), Kumar \& Sharma (2019), Poturak \& Softić (2019), Artanti et al. (2019), Ansari et al. (2019) dan Jamaludin et al. (2015)

Berdasarkan hasil analisis pengaruh Social Media Marketing terhadap Brand Awareness diperoleh nilai Signifikansi sebesar 0,000 dengan nilai koefisien beta 0,742 bernilai positif. Nilai Signifikansi $0,000<0,05$ mengindikasikan bahwa $\mathrm{H}_{0}$ ditolak dan $\mathrm{H}_{1}$ diterima. Hasil ini mempunyai arti bahwa Social Media Marketing berpengaruh positif dan signifikan terhadap Brand Awareness. Semakin baik 
tingkat Social Media Marketingnya, maka tingkat Brand Awareness pada Starbucks Coffee juga akan semakin baik. Hasil ini sesuai dengan penelitian sebelumnya yang dilakukan oleh Dewi \& Jatra (2018), Tarigan \& Tritama (2016), Elaydi (2018),Jokinen (2016), Colicev et al. (2018), Stojanovic et al. (2018) dan Yapa (2017)

Berdasarkan hasil analisis pengaruh Brand Awareness terhadap Keputusan Pembelian diperoleh nilai Signifikansi sebesar 0,000 dengan nilai koefisien beta 0,437 bernilai positif. Nilai Signifikansi $0,000<0,05$ mengindikasikan bahwa $\mathrm{H}_{0}$ ditolak dan $\mathrm{H}_{3}$ diterima. Hasil ini mempunyai arti bahwa Brand Awareness berpengaruh positif dan signifikan terhadap Keputusan Pembelian. Hal ini menandakan semakin baik Brand Awareness, maka Keputusan Pembelian pada produk Starbucks Coffee akan semakin baik. Hal ini sejalan dengan penelitian sebelumnya yang dilakukan oleh Siali \& Mahani (2016), Akhtar et al. (2015), Dharma \& Sukaatmadja (2015)

Kesadaran konsumen yang tinggi akan kekuatan suatu merek dapat mampu mengenali atau mengingatnya. Saat ini masih banyak konsumen yang belum menyadari merek pada suatu produk karena kurangnya kegiatan pemasaran. Oleh karena itu, perusahaan harus melakukan upaya untuk menarik konsumen yang lebih banyak. Pemasaran internet adalah sisi pemasaran dari e-commerce, terdiri dari upaya perusahaan untuk berkomunikasi tentang mempromosikan dan menjual barang atau jasa melalui internet. Upaya tersebut dapat mempermudahkan dalam melakukan kegiatan pemasaran dengan memperluas jangkauan pasar. Perusahaan juga harus memberikan kebutuhan yang diinginkan konsumen sehingga dapat menjadi alternatif keputusan pembelian. Sesuai dengan penelitian terdahulu menurut Goyal et al. (2019) dan Gabriel \& Kolapo (2015) menyatakan bahwa pemasaran internet mempunyai pengaruh terhadap keputusan pembelian secara positif dan signifikan. Sedangkan menurut Wibowo (2015) menyatakan bahwa pemasaran internet mempunyai pengaruh terhadap kesadaran merek secara positif dan signifikan.

Hasil penelitian ini memberikan kontribusi empiris tentang hubungan antara variabel social media marketing, brand awareness, dan keputusan pembelian bagi pengembangan ilmu pemasaran. Pengolaan data dilakukan dengan teknik analisis jalur (path analysis) untuk memperkirakan hubungan kausalitas antara variabel-variabel yang telah ditetapkan sebelumnya berdesarkan kajian teori, uji asumsi klasik juga digunakan dalam pengolahan data yang dilakukan pada penelitian ini dengan tujuan untuk memastikan hasil yang diperoleh telah memenuhi asumsi dasar di dalam analisis regresi.

Penelitian ini juga menggunakan uji sobel untuk menguji kekuatan pengaruh tidak langsung variabel social media marketing terhadap keputusan pembelian melalui variabel brand awareness. Hasil penelitian ini diharapkan dapat digunakan untuk memperkaya refrensi dan ilmu pengetahuan yang berkaitan dengan variabel social media marketing, brand awareness, dan keputusan pembelian. Hasil penelitian ini dapat menjadi refrensi bagi perusahaan Starbucks Coffee dalam memanfaatkan aspek brand awareness dan meningkatkan social media marketing yang baik bagi konsumennya, sehingga 
mampu meningkatkan nilai produk pada benak konsumen yang pada akhirnya menciptakan keputusan pembelian pada konsumen.

Ruang lingkup penelitian ini terbatas sehingga hasil tidak dapat digeneralisasi untuk konsumen Starbucks Coffee di luar wilayah Kota Denpasar. Penelitian hanya dilakukan dalam titik waktu tertentu (cross section), sedangkan lingkungan dan kebutuhan bersifat dinamis, sehingga penelitian ini penting dilakukan kembali di masa yang akan datang dengan menambah variabel lain yang tidak dimasukkan di dalam model yang juga dapat memengaruhi keputusan pembelian.

\section{SIMPULAN}

Social Media Marketing berpengaruh positif terhadap Brand Awareness. Semakin baik tingkat Social Media Marketing, maka tingkat Brand Awareness juga akan semakin baik. Social Media Marketing berpengaruh positif terhadap Keputusan Pembelian. Hal ini menandakan semakin baik Social Media Marketingnya, maka Keputusan Pembelian akan semakin baik. Brand Awareness berpengaruh positif terhadap Keputusan Pembelian. Hal ini menandakan semakin baik Brand Awareness maka Keputusan Pembelian akan semakin baik. Brand Awareness memediasi pengaruh Social Media Marketing terhadap Keputusan Pembelian. Hal ini menunjukan bahwa Social Media Marketing memberikan dampak yang signifikan terhadap Keputusan Pembelian jika di mediasi oleh Brand Awareness, yang berarti bahwa Keputusan Pembelian sangat tergantung pada tingkat Brand Awareness dan juga tingkat Social Media Marketing.

Variabel social media marketing dalam penelitian ini yang memiliki rata-rata terendah dengan nilai sebesar 3,65 termasuk ke dalam kriteria baik dengan pernyataan "Starbucks Coffee mampu menyampaikan informasi yang lengkap mengenai produk, dan lokasi store melalui social media". Ini menunjukkan bahwa informasi produk yang disampaikan di social media kurang terinci. Untuk itu sebaiknya manajer perusahaan mengupayakan informasi lebih detail seperti mengupdate informasi mengenai produk-produk baru yang dikeluarkan dan lokasi store agar konsumen lebih mengetahui produk terbaru dan lokasi Starbucks Coffee.

Variabel brand awareness dalam penelitian ini yang memiliki rata-rata terendah dengan nilai sebesar 3,13 termasuk ke dalam kriteria cukup dengan pernyataan "Saya dapat membedakan produk merek Starbucks Coffee dengan produk lain". Ini menunjukkan bahwa brand awareness yang sudah dibentuk Starbucks sudah memiliki top of mind di masyarakat, namun belum bisa mendiferensiasikan produknya dengan produk pesaing. Ketika ada faktor-faktor lain yang memengaruhi brand awareness seperti promosi yang gencar dari pesaing, maka kemungkinan brand awareness dari Starbucks juga akan terpengaruh. Jika produk dari pesaing lebih unik, maka untuk mempertahankan brand awareness pihak manajemen Starbucks sebaiknya lebih meningkatkan diferensiasi produknya dengan menghadirkan varian produk yang unik berdasarkan season tertentu seperti Chinese New Year, holiday, Halloween day.

Variabel keputusan pembelian dalam penelitian ini yang memiliki rata-rata terendah dengan nilai sebesar 3,28 termasuk ke dalam kriteria cukup baik dengan 
pernyataan "Saya bersedia berkorban waktu dan biaya untuk membeli produk Starbucks Coffee". Ini menunjukkan tidak semua konsumen bersedia mengorbankan waktu dan biayanya untuk membeli produk Starbucks. Untuk itu manajer perlu meningkatkan promosi guna menarik perhatian konsumen untuk membeli produk Starbucks, seperti melalui Monday madness promotion, by one get one, by two get three promotion, dan meningkatkan promosi tumbler day untuk mendapatkan potongan setengah harga setiap pembelian minuman apa saja.

\section{REFERENSI}

Akhtar, N., Qurat, U. A., \& Umer, I. S. (2015). Impact of a Brand Equity on Consumer Purchase Decision in L'Oreal Skincare Products. International Journal Review of Management and Business Research, 5(3), 178-191.

Ansari, S., Ansari, G., Ghori, M. U., \& Kazi, A. G. (2019). Impact of Brand Awareness and Social Media Content Marketing on Consumer Purchase Decision. Journal of Public Value and Administration Insights, 2(2), 5-10. https://doi.org/10.31580/jpvai.v2i2.896

Artanti, Y., Hari Prasetyo, F., \& Sulistyowati, R. (2019). How Social Media Marketing Influences Online Purchasing Decision: Study of the Viral Marketing and Perceived Ease of Use. KnE Social Sciences, 3(11), 988. https://doi.org/10.18502/kss.v3i11.4066

Ayuningtyas, A. S., Achmad, F., \& Nuralam, I. P. (2019). Pengaruh Terpaan Social media Instragram terhadap Keputusan Berkunjung dengan Citra Destinasi sebagai Variabel Mediasi (Survei pada Pengunjung Kampung Tridi (Tiga Dimensi) Malang). Jurnal Administrasi Bisnis (JAB), 68(1), 45-54.

Chang, C. (2016). The Influence of Social Power in Online Purchase Decision. British Journal of Applied Science and Technology, 12(6), 1-16.

Colicev, A., Malshe, A., \& Pauwels, K. (2018). Social Media and Customer-Based Brand Equity: An Empirical Investigation in Retail Industry. Administrative Sciences, 8(3), 55. https://doi.org/10.3390/admsci8030055

Dewi, D. A. D. P., \& Jatra, I. M. (2018). Peran Brand Awareness dalam Memediasi Pengaruh Social media marketing terhadap Niat Beli. E-Jurnal Manajemen Unud, 7(9), 4599-4627.

Dharma, N. P. S. A., \& Sukaatmadja., I. (2015). Pengaruh Citra Merek, Kesadaran Merek, dan Kualitas Produk Terhadap Keputusan Pembelian Produk Apple. E-Jurnal Manajemen Unud, 4(1), 1-20.

Edyl, I. C., \& Brotojoyo, E. (2017). Kajian Model Empiris : Penggunaan Social media terhadap Life Style dan Keputusan Pembelian. Geotik, 1(1), 2580-8796. 
Elaydi, H. O. (2018). The Effect of Social Media Marketing on Brand Awareness through Facebook: An Individual-Based Perspective of Mobile Services Sector in Egypt. OALib, 05(10), 1-5. https://doi.org/10.4236/oalib.1104977

Gabriel, J., \& Kolapo, S. (2015). Online Marketing and Consumer Purchase Behaviour: a Study of Nigerian Firms. British Journal of Marketing Studies, 3(7), 1-14.

Goyal, A., Kumar, V., \& Bansal, S. (2019). Impact of the Packaging on Consumer Buying Behaviour. People, Planet and Profit in Sustainable Development \& Contribution in IT, Media and Management, 1(5), 1-14.

Herdana, A. (2015). Analisis Pengaruh Kesadaran Merek (Brand Awareness) pada Produk Asuransi Jiwa Prudential Life Assurance (Studi Pada Pru Passion Agency Jakarta). Jurnal Riset Bisnis Dan Manajemen, 3(1), 1-18.

Jamaludin, A., Zainul, A., \& Kadarismas, H. (2015). Pengaruh Promosi Online dan Persepsi Harga terhadap Keputusan Pembelian (Survei pada Pelanggan Aryka Shop di Kota Malang). Jurnal Administrasi Bisnis (JAB), 21(1), 1-8.

Jokinen, T. (2016). Branding in Social Media and the Impact of Social Media on Brand Image. Business and Culture, 1(1), 1-20.

Kshetri, A., \& Jha, B. (2016). Online Purchase Intention: A Study of Automobile Sector in India. Review of Integrative Business and Economic Research, 5(3), $35-59$.

Kumar, A., \& Sharma, N. K. (2019). Impact of Social Media on Consumer Purchase Intention. Journal of Marketing and Consumer Research, 56(1), 260-277. https://doi.org/10.4018/978-1-7998-1279-1.ch017

Lubis, I. B. H., \& Wibowo, M. E. I. A. (2016). Pengaruh Citra Merek, Media Iklan Instagram, dan Persepsi Kualitas terhadap Keputusan Pembelian Produk Vans. Jurnal Manajemen Universitas Negeri Yogyakarta, 1(1), 388-401.

Mileva, L., \& Fauzi, D. A. (2018). Pengaruh Social Media Marketing terhadap Keputusan Pembelian (Survei Online pada Mahasiswa Sarjana Jurusan Ilmu Administrasi Bisnis Angkatan 2014/2015 Fakultas Ilmu Administrasi Universitas Brawijaya yang Membeli Starbucks Menggunakan LINE). Jurnal Administrasi Bisnis (JAB), 58(1), 190-199.

Muslim, A. W. (2018). Pengaruh Social media, E-Service Quality dan Harga terhadap Keputusan Pembelian yang di Mediasi Oleh Gaya Hidup. Jurnal Riset Dan Manajemen, 6(2), 145-162.

Poturak, M., \& Softić, S. (2019). Influence of Social Media Content on Consumer 
Purchase Intention: Mediation Effect of Brand Equity. Eurasian Journal of Business and Economics, 12(23), 17-43. https://doi.org/10.17015/ejbe.2019.023.02

Putri, C. S. (2016). Pengaruh Social media terhadap Keputusan Pembalian Konsumen Cherie melalui Minat Beli. PERFORMA: Jurnal Manajemen Dan Start-Up Bisnis, 1(5), 594-603.

Siali, F. P. J., \& Mahani, M. A. (2016). Relationship Between Brand Equity and Consumer Purchase Decision: A Case of An International Brand of Footwear. International Journal of Service Management and Sustainability (IJSMS), $1(1), 58-74$.

Stojanovic, I., Andreu, L., \& Curras-Perez, R. (2018). Effects of the intensity of use of social media on brand equity: An empirical study in a tourist destination. European Journal of Management and Business Economics, 27(1), 83-100. https://doi.org/10.1108/EJMBE-11-2017-0049

Tarigan, R., \& Tritama, H. B. (2016). The Effect of Social Media to the Brand Awareness of A Product of A Company. CommIT (Communication and Information Technology) Journal, $\quad 10(1), \quad 9$. https://doi.org/10.21512/commit.v10i1.904

Wibowo, A. P. P. (2015). Analisis Pengaruh Internet Marketing Terhadap Pembenukan Brand Awareness Pada perusahaan Grosir Pakaian OMR GROUP SOLO. Jurnal Administrasi Bisnis, 1(1), 1-20.

Yapa, U. A. S. (2017). The Impact of Social Media on Brand Awareness ( With Special Reference to Facebook Use in Fast Moving Consumer Goods in Sri Lanka ). International Journal of Engineering and Management Research, 7(5), 262-272. 